\title{
Improving Efficiency of Photovoltaic Cell Using Nanomaterials
}

\author{
BATOOL MEMON*, SAIMA JATOI*, ZEESHAN ALI**, JAVED RAHMAN LARIK***, \\ LIAQUAT ALI JAMROF****
}

\section{RECEIVED ON 27.06.2018, ACCEPTED ON 19.02.2019}

\begin{abstract}
Conventional solar cells are not economical and are recently too expensive to the manufacturers for extensive-scale electricity generation. Cost and efficiency is most vital factor in the accomplishment of any solar technology. In order to improve the conversion efficiency, the major research in thirdgeneration photovoltaic $(\mathrm{PV})$ cells is directed toward retaining more sunlight using nanotechnology. Advancement in nanotechnology solar cell via quantum dots (QDs) could reduce the cost of PV cell and additionally enhance cell conversion efficiency. Silicon quantum dots (Si-QDs) are semiconductor nano crystals of nanometers dimension whose electron-holes are confined in all three spatial dimensions. Quantum dots have discrete electronic states. Quantum dots have capacity to change band gap with the adjustment in size of quantum dot. As the quantum dots size fluctuates over a wide range that demonstrates the variety of band gap so it will assimilate or discharge light. In this paper, the generic mathematical models of $P V$ cell are adopted and then I-V and P-V characteristic curves are obtained from selected parameters using MATLAB software. The essential parameters are taken from datasheets. I-V and P-V characteristics curves are obtained for selected model. Silicon quantum dots have the tunable band gap that is added to conventional PV cell and obtain the I-V and P-V curves. After simulation, efficiency and power of Conventional PV cell to quantum dots based PV cell is compared. The property of quantum dots is used in extending the band gap of solar cells and increasing the maximum proportion of incident sunlight absorbed, hence improving efficiency.
\end{abstract}

Keywords: Photovoltaic, Silicon Quantum dots, Efficiency, Characteristics of PV cell, Bandgap

\section{INTRODUCTION}

$\mathrm{T}$

The world energy consumption is increasing at a very high pace, and ongoing increase in the degree of greenhouse gas emissions, and a rise in fuel costs are main causes for effectively exploiting numerous sources of green energy. This lead to an urgent need for the alternatives for electricity. Solar energy is an excellent choice for the generation of electricity, because it is a clean, contamination free, limitless, and has no significant damage to the environment. An innovation that converts free solar energy into electrical power while not

Authors E-Mail: (Jatoi_49@yahoo.com, zeeshan.ali@faculty.muet.edu.pk,javedlarik@gmail.com,engr_laj@yahoo.com,batoolmemon94@gmail.com) * Department of Mechatronics Engineering, IICT, MUET, Jamshoro.

** Department of Industrial Engineering and Management, Dawood UET, Karachi.

*** Department of Mechanical Engineering, MUET, Jamshoro.

**** Sindh Technical Education and Vocational Training Authority, Karachi.

This is an open access article published by Mehran University Research Journal of Engineering and Technology, Jamshoro under the CC by 4.0 International License. 
inflicting any contamination to the environment is alluded as photovoltaic (PV) electric-power-generation [1]. Solar energy based power generation continues to be difficult due to small efficiency, high manufacturing cost \& unbalanced power gain of the PV modules. The applications of solar energy are expanding and numerous analysts are focusing to enhance the materials and techniques to tackle this power source. Nanotechnology has opened up innovative and favorable potential outcomes to enhance the quality of environment, efficiency, and economic development [2]. Nanotechnology is successful in energy application. The energy efficient solar panels are being developed by introducing the nanomaterial. These days, $3^{\text {rd }}$-generation solar cells such as silicon quantum dots based solar cells, are ensuring a sizable increase in power conversion performance. The addition of silicon quantum dots (SiQDs) shows a reduction in the energy space with increasing dimension of Si-QDs [3]. Traditional PV cells where in one photon generates one electron whereas the quantum dots have the ability to convert high energy photon into more than one electrons [4]. A single PV cell is too small for electricity technology; therefore, it is typically consolidated in arrangement of parallel blends to offer a required voltage and current which is named as the PV module. In the first half of this paper, a generic numerical model of a PV module is adopted and analyzed to lay the foundation for the further development of the proposed model. The output power of a PV cell is significantly affected by the solar irradiance and the cell temperature; therefore, the $\mathrm{I}-\mathrm{V} \& \mathrm{P}-\mathrm{V}$ characteristic curves are initially simulated and analyzed for different irradiance, and temperature values. It is noticeable that the conventional PV has very low efficiency, therefore, the research efforts should be made to improve the overall performance of the conventional PV cells. In the next half of the paper, the conventional PV cell model is modified by adding the Si-QDs. The addition of Si-QDs redefines the energy band gaps, thus, the outer valence shell electrons need less energy to knock out from their positions. The I-V \& P-V characteristic figures of the modified PV module are then imitate in the MATLAB software. Furthermore, the comparative analysis of both models has been discussed to realize the significance of the modified model. Using this comparative analysis, the efficient model can be selected for further development in the technology.

\section{How A PV CELL WORKS}

Basically photovoltaic cell is the P-N junction device fabricated from the semiconductor material silicon. Once the PN junction is subjected to light (photons), with energy higher than the gap energy is assimilated causing the development of electron-hole pairs. The internal electric field of the PN junction separates these carriers which results in current flow which is directly proportional to the magnitude of solar irradiance [6]. This process relies on the material of the semiconductor and the wavelength of the incident radiation. A PV system in a natural way demonstrates nonlinear I-V \& P-V performance graphs which change with respect to the illumination level and cell temperature. Solar cells are connected in series arrangement to yield the outcome voltage, and are linked in parallel to produce better current [7].

\section{MATHEMATICAL MODELING OF PV MODULE}

The use of mathematical equations and appropriate electric circuits make it conceivable to display the performance of PV cell and simulate it. The identical model also can be modified for modeling and simulating a PV module and PV array. It is essential to create a generic model that is appropriate for scaling in any respect tiers, i.e. the PV cell, module, and array [8]. 


\subsection{Single Diode Model of PV Cell}

The model of a PV cell is defined by the equivalent circuit or numerical equations. A lumped circuit model is generally used to describe the terminal electrical execution of the solar cell. The identical circuit of the generic model comprises of a photocurrent, a diode, a shunt resistor which represents a leakage-current, and a series resistor which is responsible for inner resistance to the flow of current. The response of I-V \& P-V attributes of the PV cell are nonlinear and are the function of occurrence light and cell temperature. A single-diode's identical circuit is shown in Fig. 1 [9].

The voltage-current characteristics equation of a solar cell is given as (1-3) [10].

$$
\begin{aligned}
& I=I L-I D-I_{s h} \quad I=I_{L}-I_{D}-I_{s h} \\
& I=I_{L}-I_{s}\left[\exp \left(\frac{V+I \cdot R_{s}}{N_{s \cdot n \cdot V_{t}}}\right)-1\right]-\left[\frac{V+I \cdot R_{s}}{R_{s h}}\right] \\
& V t=K \cdot T_{c} / q V t=K \cdot T_{c} / q
\end{aligned}
$$

Where $I_{L}$ is the light generated current because of sunlight, $I_{D}$ is a current across the diode, $I_{s}$ is a diode reverse saturation current, $q$ is the charge of electron $\left(1.6 * 10^{-19}\right)$, $K$ is a Boltzmann constant $\left(1.38^{*} 10^{-23} \mathrm{~J} / \mathrm{K}\right), n$ is an ideality factor, $V$ is a cell output voltage, $I$ is a cell terminal current, $T_{c}$ is a working cell temperature in Kelvin. $R_{s}$ is the series resistance, and $R_{s h}$ is the shunt resistance, $V_{t}$ is terminal voltage. The light generated current relies upon the cell's temperature and solar radiation and can be expressed as equation (4)

$$
I_{L}=\left[I_{s c}+k_{i} \cdot\left(T_{c}-T_{r e f}\right)\right] \cdot \lambda
$$

Where $I_{s c}$ is the short-circuit current taken at $1 \mathrm{KW} / \mathrm{m}^{2}$ and $25^{\circ} \mathrm{C}, k_{i}$ is the temperature coefficient corresponding to short circuit current $\left(3 \mathrm{~mA} /{ }^{\circ} \mathrm{C}\right), \lambda$ is the solar insolation which is measured in $\mathrm{KW} / \mathrm{m}^{2}$ and $T_{r e f}$ is the reference signal for temperature. The expression for saturation current is represented by equation (5)

$$
I_{s}=I_{r s} \cdot\left(T_{c} / T_{r e f}\right)_{3} \cdot \exp \left(q \cdot E_{g} \cdot\left(\frac{1}{T_{r e f}}-\frac{1}{T_{c}}\right) K \cdot n\right)
$$

Where $I_{r s}$ is the opposing saturation-current at a reference temperature, $q$ is the charge of an electron, and $E_{g}$ is the band gap energy of the semiconductor material. The expression of Irs is described as equation (6)

$$
I_{r s}=I_{s c} /\left[\exp \left(q \cdot V_{o c} / N_{s} \cdot K \cdot n \cdot T_{c}\right)-1\right]
$$

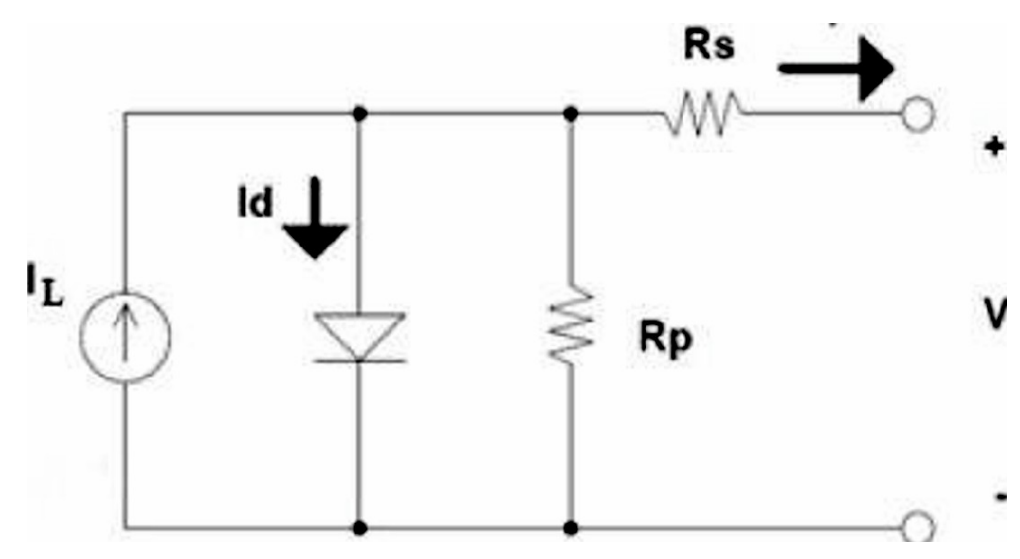

FIG.1. SINGLE DIODE MODEL OF PV CELL [9]. 
Where $V_{o c}$ is open circuit voltage and $N_{s}$ is the number of cells connected in series

\subsection{Single Diode Model for PV Module}

The power produced by a single PV cell is roughly less than $2 \mathrm{~W}$ at $0.5 \mathrm{~V}$, therefore, the cells needs to be linked in series-parallel arrangements on a module to produce enough power. A PV cluster is a collection of a number of PV cells that are connected in series-parallel arrangements to create the necessary voltage and current. The overall output current of a PV panel with $N_{p}$ and $N_{s}$ is given as equation (7). Fig. 2 shows a PV panel with parallel $\left(N_{p}\right)$ and series $\left(N_{s}\right)$ cells [10].

The voltage-current expression of PV module is given by equation (7)

$$
I=N_{p} \cdot I_{p h}-N_{p} \cdot I_{s} \cdot\left[\exp \left(q\left(\frac{V}{N_{s}}+\frac{I \cdot R_{s}}{N_{p}}\right) / k \cdot T_{c} \cdot n\right)-1\right]
$$

\subsection{Efficiency of PV Cell}

Portion of output power of the solar cell to input energy from the sun is described as efficiency. The numerical equation for the efficiency of a PV cell can be expressed as equation (8)

$\eta=\frac{V_{m p} \cdot I_{m p}}{I \cdot A} \eta=\frac{V_{m p} \cdot I_{m p}}{I \cdot A}$ where, $I_{m p}$ represents the current at maximum power, $V_{m p}$ represents the voltage at maximum power, $I$ is termed as intensity of solar radiatoin per square meter, and $A$ is the area where the solar radiation strikes [11].

\section{$4 \quad$ SILICON QUANTUM DOTS (SI-QDS)}

Nanomaterials provide distinctive possibilities in engineering and green energies. The real photovoltaic market is driven by silicon solar collectors. In any case, to cover the upcoming demand of electric power in the order of $\sim 30$ Terawatts, value of solar electricity need to be considerably decreased with excessive performance. In an effort to improve the efficiency and minimize the cost, research is focused to third generation cells in the last few years with respect to finding an effective opportunity for silicon-based solar cells. The third generation solar cell tends to include the nonsemiconductor solutions (including polymers) quantum dot technologies to higher size incident light [12]. Quantum dots are semiconductor nano crystals of nanometer size whose electron holes are constrained in all dimensions. They got quantum-optical properties that are not realized in bulk material due to the characteristics of quantum confinement exhibited by means the nanoscale structures. Quantum dots have the ability to change band gap with the change in the dimension of the quantum dot so that the wavelength at which it is going to absorb or emit light may be modified for a particular application.

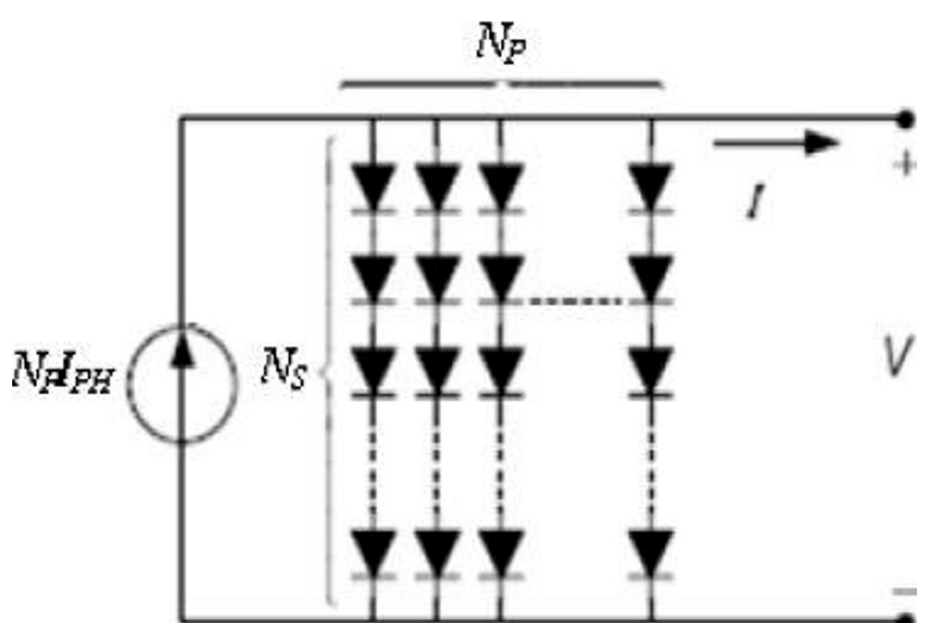

FIG.2. SINGLE DIODE MODEL WITH $N_{S} A N D N_{P}[10]$.

Mehran University Research Journal of Engineering \& Technology, Volume 39, No. 1, January, 2020 [p-ISSN: 0254-7821, e-ISSN: 2413-7219] 
This property of quantum dot is utilized in extending the band gap of solar cells and increasing the most percentage of incident light absorbed, subsequently enhancing efficiency [3, 13]. Fig. 3 shows the relationship between the band gap and quantum dot size [14], by increasing the size of quantum dots the band gap decrease and it requires less energy to knock out an electron from its valence shell.

\section{SIMULATION RESULTS AND DISCUSSION}

In order to investigate the performance of PV cell model, simulation is completed in MATLAB environment. Solarex MSX60 [15] module has been chosen for the modeling of a PV panel. This panel has 36 series linked polycrystalline cells. The main features of the PV panel are shown in Table 1.The behaviour of the solar cell is generally evaluated under the Standard Test Conditions (STC), where an average solar spectrum at A.M 1.5 is used, the irradiance of $1 \mathrm{KW} / \mathrm{m}^{2}$, and the temperature is $25^{\circ} \mathrm{C}$

\subsection{Simulation Results for Different Temperature Levels}

In Fig. 4(a), the generic model of PV cell current in Equation (7) is plotted against voltage for different temperature levels. Since these results have been validated with the previous studies [10], therefore, this ensures that the mathematical model can be modified for incorporating the impact of silicon quantum dots (Si-QDs) [13]. Fig. 4(b) shows the output power to the voltage at various temperature levels to ensures the validated response of the generic model. Both $\mathrm{I}-\mathrm{V} \& \mathrm{P}-\mathrm{V}$ results at distinct temperature with constant irradiance $\left(1 \mathrm{KW} / \mathrm{m}^{2}\right)$ are obtained as shown in Fig. 4(a) and 4(b) respectively. Fig. 4(b) depicts that the output power decreases with the increment of temperature values.

\subsection{Simulation Results for Different Irradiance Levels}

In order to ensure the validation of the developed simulation results, the I-V \& P-V performance plots are generated for distinct irradiance levels while keeping the temperature same $25{ }^{\circ} \mathrm{C}$ in both cases, as shown in Fig. 5(a) and Fig. 5(b). This analysis helps in understanding

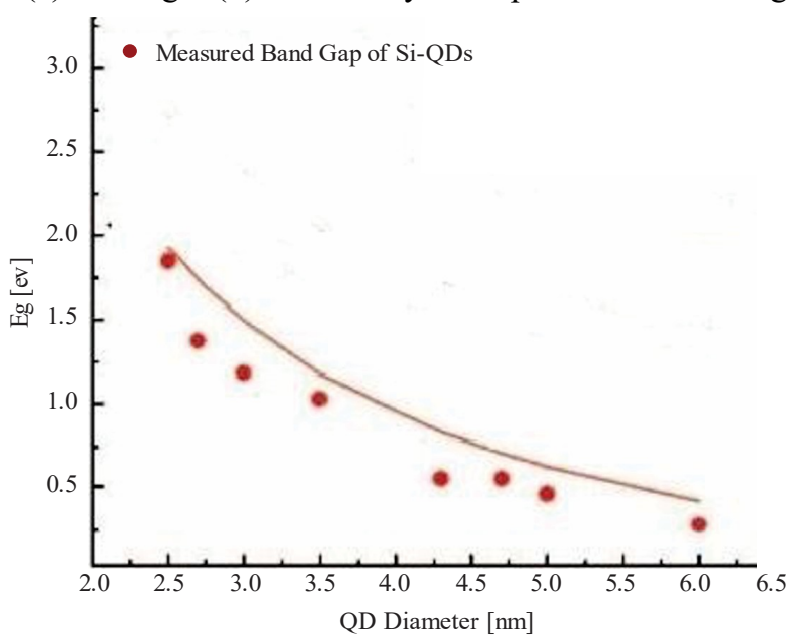

FIG.3. RELATIONSHIP BETWEEN THE SIZE OF QD AND $B A N D$ GAP [14]

TABLE 1: SOLAREX MSX60 SPECIFICATION $\left(1 \mathrm{KW} / \mathrm{m}^{2} \& 25^{\circ} \mathrm{C}\right)$

\begin{tabular}{|c|c|}
\hline Characteristics & Specification \\
\hline Maximum power $\left(\mathrm{P}_{\mathrm{mp}}\right)$ & $60 \mathrm{~W}$ \\
\hline Voltage at maximum power $\left(\mathrm{V}_{\mathrm{mp}}\right)$ & $17.1 \mathrm{~V}$ \\
\hline Current at maximum power $\left(\mathrm{I}_{\mathrm{mp}}\right)$ & $3.5 \mathrm{~A}$ \\
\hline Short Circuit Current $\left(\mathrm{I}_{\mathrm{sc}}\right)$ & $3.8 \mathrm{~A}$ \\
\hline Open circuit Voltage $\left(\mathrm{V}_{\mathrm{oc}}\right)$ & $21.1 \mathrm{~V}$ \\
\hline Temperature Coefficient at short circuit current $\left(\mathrm{K}_{\mathrm{i}}\right)$ & $0.003 \mathrm{~A} /{ }^{\circ} \mathrm{C}$ \\
\hline Cell type & Poly crystalline \\
\hline Nominal Temperature & $47 \pm 2$ \\
\hline
\end{tabular}


the behavior of a PV cell model in detail for various influencing parameters. These results have been validated with the existing literature [10]. Fig. 5(b) displays that the output power expands with the increment of irradiance level.

\subsection{Simulation Results for Si-QDs}

The simulation results of Si-QDs based solar cell are presented and discussed in this section. From Fig. 3, it is clear that various sizes of Si-QDs have a significant impact on the energy band gap; therefore, the generic PV cell model has been modified by adding the Si-QDs. In this study, three different sizes of Si-QDs are used which are $3.5 \mathrm{~nm}, 4.25 \mathrm{~nm}, 6 \mathrm{~nm}$, and after the addition, the I-V\& $\mathrm{P}-\mathrm{V}$ performance figures at distinct temperatures values as shown in Fig.(6-8) respectively.

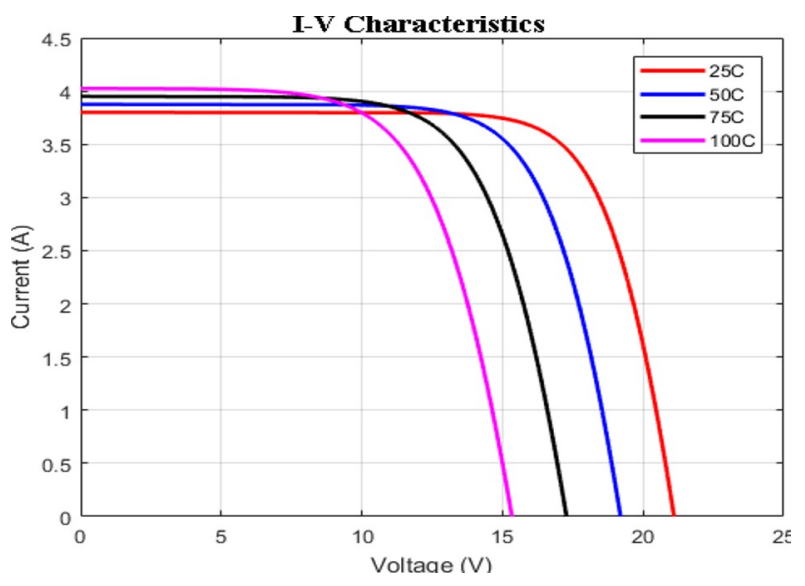

FIG. 4(A) I-V RESULTS AT VARIOUS TEMPERATURE

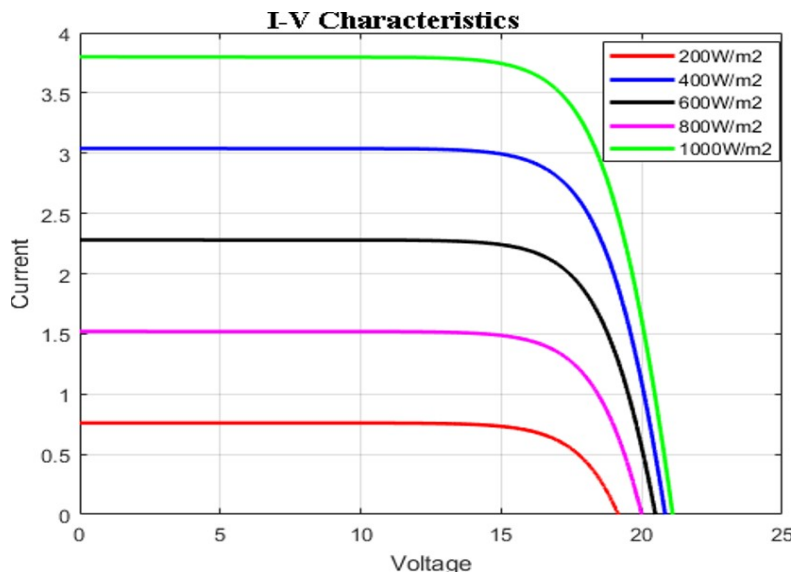

FIG. 5(A) I-V RESULTS AT DISSIMILAR IRRADIANCE LEVEL
As the size of Si-QDs are increased the band gap is reduced as shown in fig 3. Solar cells are sensitive to temperature. Increase in temperature reduce the band gap of a semiconductor as increasing the energy of electrons in the material. In conventional PV cell the silicon semiconductor is used. The proposed modified module uses the the silicon quantum dots. By using the siliocn quantum dots the band gap is adjusted.The simulation results show that the output power increases with the increase in the size of the Si-QDs. Hence, the efficiency of the PV cell in flip will increases. The power of conventional PV module is decreases as the temperature rises as shown in fig.4(b), but as compared to the proposed modified PV module can produce more power for the same given input irradiance and temperature value. The energy gap, the corresponding output power and the corresponding performance of the PV module are presented in Table. 2 . The efficiency has been calculated

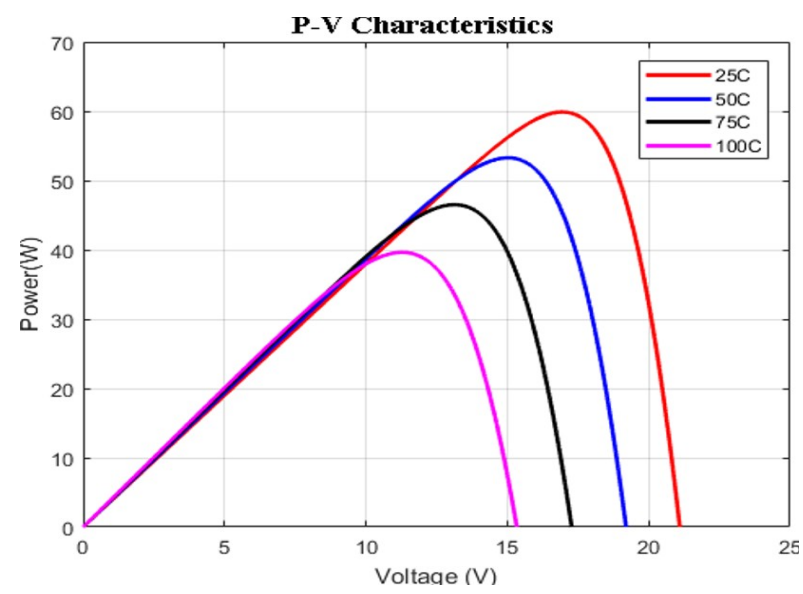

FIG. 4(B) P-V RESULTS AT VARIOUS TEMEPRATURES

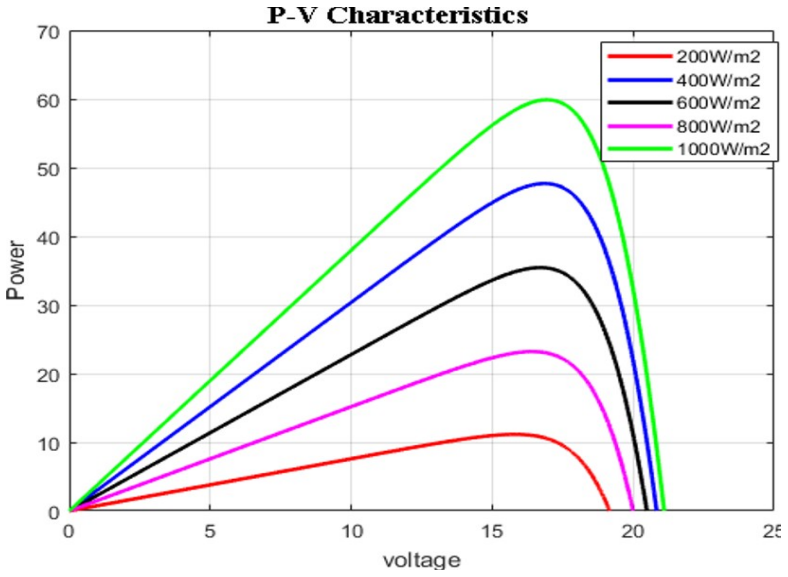

FIG.5(B) P-V RESULTS AT DISSIMILAR IRRADIANCE LEVEL

Mehran University Research Journal of Engineering \& Technology, Volume 39, No. 1, January, 2020 [p-ISSN: 0254-7821, e-ISSN: 2413-7219] 
by using equation (8). It is evident from the outcomes that the addition of a nanomaterial that is by changing

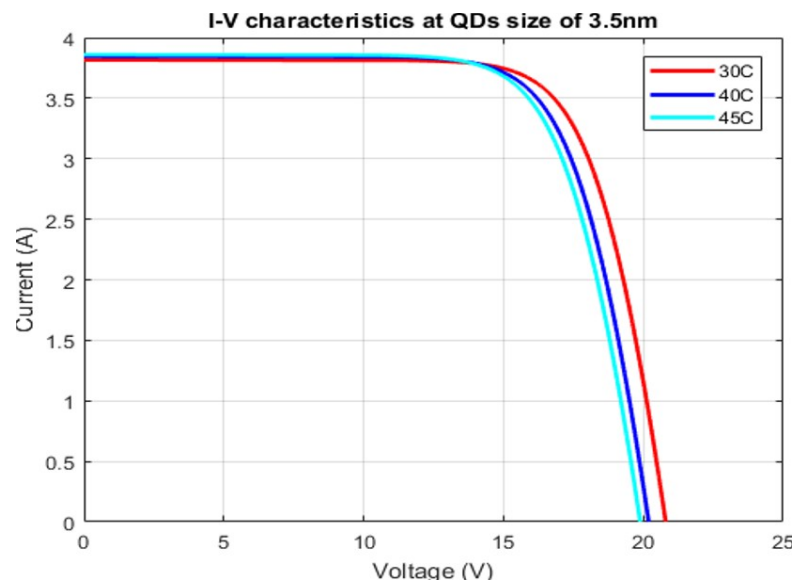

FIG.6(A) I-V RESULTS AT DISTINCT TEMPERATURE

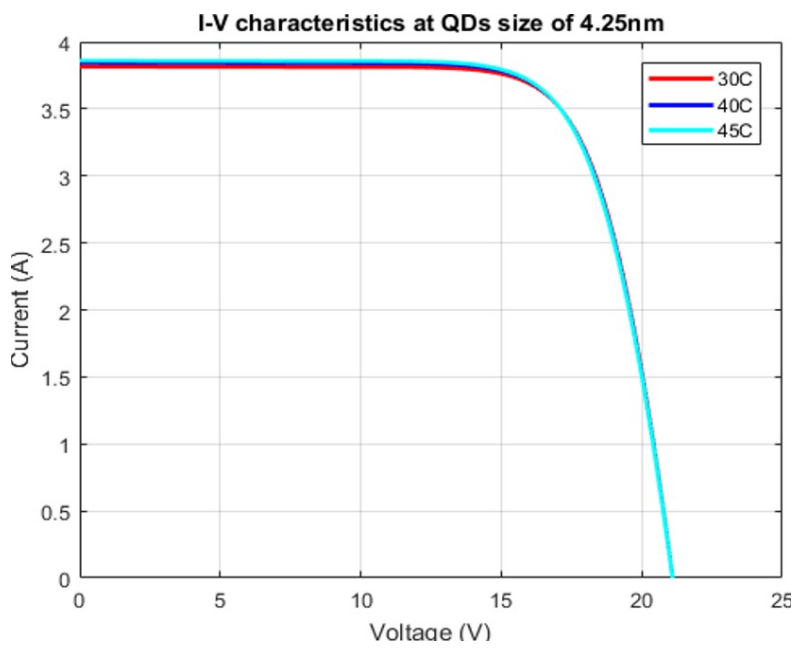

FIG.7(A) I-V RESULTS AT DISSIMILAR TEMPERATURE

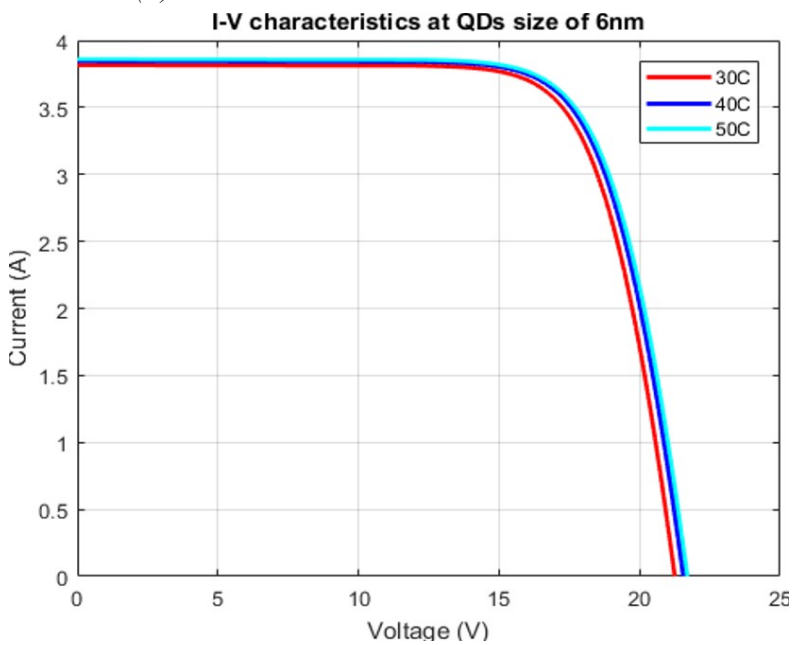

FIG. 8(A) I-V RESULTS AT VARIOUS TEMPERATURE the band gap of QDs, can enhance the efficiency of conventional PV cells.

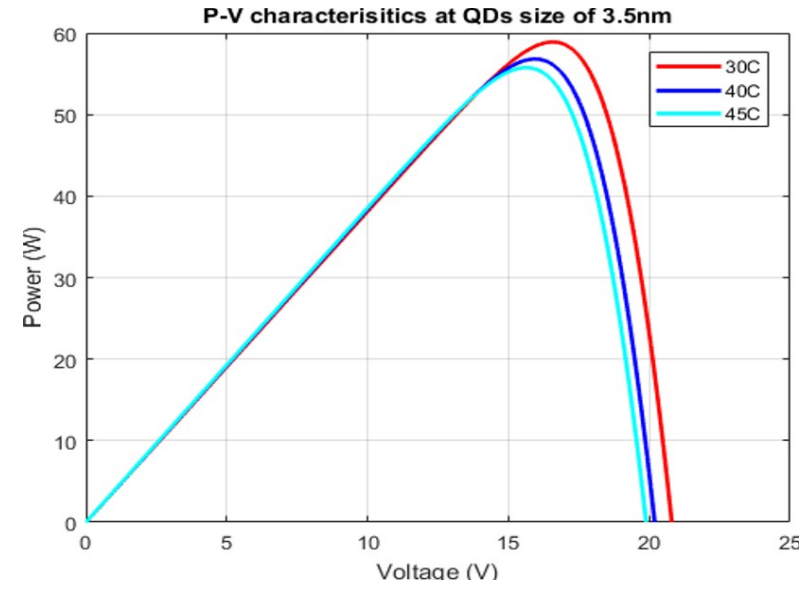

FIG.6(B) P-V RESULTS AT DISTINCT TEMPERATURE

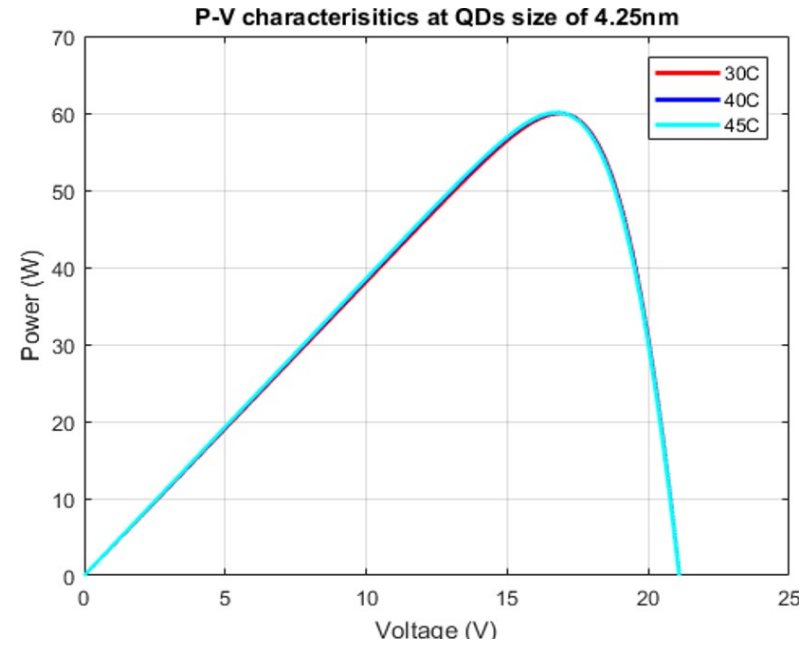

FIG. 7(B) P-V RESULTS AT DISSIMILAR TEMPERATURE

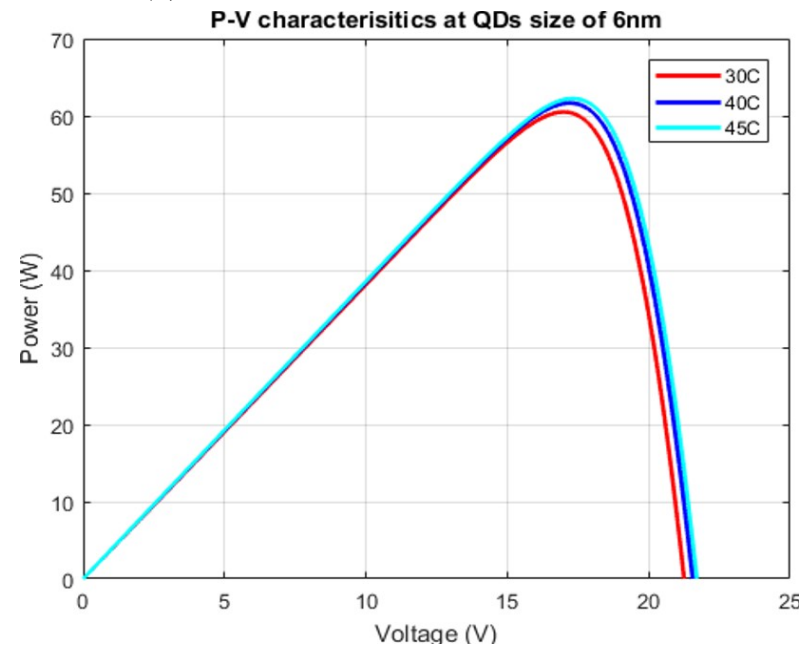

FIG. 8(B) P-V RESULTS AT VARIOUS TEMPERATURE

Mehran University Research Journal of Engineering \& Technology, Volume 39, No. 1, January, 2020 [p-ISSN: 0254-7821, e-ISSN: 2413-7219] 
TABLE 2: EFFICIENCY AND BAND GAP COMPARSION

\begin{tabular}{|c|c|c|}
\hline Energy gap (eV) & $\begin{array}{c}\text { Maximum power } \\
(\text { Pmax })\end{array}$ & Efficiency(\%) \\
\hline $1 \mathrm{eV}$ & $56 \mathrm{~W}$ & 13.3 \\
\hline $0.5 \mathrm{eV}$ & $60 \mathrm{~W}$ & 17.1 \\
\hline $0.25 \mathrm{eV}$ & $62 \mathrm{~W}$ & 20.6 \\
\hline
\end{tabular}

\section{CONCLUSION}

A generalized MATLAB PV model to illustrate the execution of PV cell has been created and been tested with a commercial module. In this research, A modified $\mathrm{PV}$ cell model is utilized to investigate the improvement in the performance of the PV cell. A PV cell is modified by adding the nanomaterial called Si-QDs with various diameter sizes such as $3.5 \mathrm{~nm}, 4.25 \mathrm{~nm}$, and $6 \mathrm{~nm}$. In order to validate the photovoltaic modeling and simulation method a reference module Solarex "MSX60" is used. Both I-V \& P-V results are generated which show the dependence of output power on the temperature and the solar irradiance. By expanding the solar irradiance output current increases, output voltage increases, thus the net output power is increased. By expanding the temperature, The output current increases but the output voltage decreases, So the net power decreases thus the efficiency is decreased. It was observed that by adding the Si-QDs the energy bandgap of the solar cell can be adjusted. Table 2 shows the efficiency and energy band and power output for different sizes of Si-QDs. Nano-coated solar cells model has been analyzed at different temperatures by simulating their I-V\& P-V performance curves. It can be concluded that by adding the nanomaterial such as $\mathrm{Si}$ QDs in this case, the efficiency of a PV cell can be significantly increased. This research study can bring a great revolution in the solar energy conversion systems as the conventional PV modules are suffering from the serious solar energy conversion issues.

\section{ACKNOWLEDGEMENT}

The Facilities provided by the department of Mechanical Engineering of Mehran University of Engineering Technology are acknowledged to carryout this research work.

\section{REFERENCES}

[1] Panwar, N. L., Kaushik, S. C., \& Kothari, S. "Role of Renewable Energy Sources in Environmental Protection," Renewable and Sustainable Energy Reviews, Volume.15, No.3, pp 1513-1524, 2011
Abdin, Z., Alim, M. A., Saidur, R., Islam, M. R., Rashmi, W., Mekhilef, S., \&Wadi, A. "Solar Energy Harvesting with the Application of Nanotechnology," Renewable and Sustainable Energy Reviews, Volume.26, pp 837-852, 2013.

[3] Manna, T. K., \& Mahajan, S. M. "Nanotechnology in the Development of Photovoltaic Cells," International Conference on Clean Electrical Power (ICCEP), pp 379-386, Italy, 2007.

[4] Sethi, V. K., Pandey, M., \& Shukla, M. P. "Use of Nanotechnology in Solar PV Cell," International Journal of Chemical Engineering and Applications, Volume.2, No.2, pp 77-80, 2011.

[5] Suthar, M., Singh, G. K., \& Saini, R. P. "Comparison of mathematical models of photovoltaic (PV) module and effect of various parameters on its performance," International Conference in Energy Efficient Technologies for Sustainability (ICEETS), pp 1354-1359, India, 2013.

[6] Lorenzo, E. "Solar Electricity Engineering of Photovoltaic Systems," Artes Graficas Gala, S.L, Spain, Chapter 2, pp 59-64, 1994.

[7] Kumari, J., \&Babu, C. S. "Mathematical Modeling and Simulation of Photovoltaic cell using Matlab-Simulink Environment," International Journal of Electrical and Computer Engineering, Volume.2, No.1, pp 26-34, 2011.

[8] Vajpai, J., Khyani, H. K. "Mathematical Modelling and Experimental Validation of Performance Characteristics of Solar Photovoltaic Modules," International Journal of Application or Innovation in Engineering and Management, Volume.2, No.11, pp 295-301, 2013.

[9] Bonkoungou, D., Koalaga, Z., \&Njomo, D. "Modelling and Simulation of Photovoltaic Module Considering single-diode equivalent circuit model in MATLAB," International Journa of Emerging Technology and Advanced Engineering, Volume.3, No.3, pp 493-502, 2013.

[10] Tsai, H. L., Tu, C. S., \& Su, Y. J. "Development of Generalized Photovoltaic Model using MATLAB/ SIMULINK," In Proceedings of the World Congress on Engineering and Computer Science (WCECS), pp 1-6, San Francisco, 2008,

[11] Mohammed, S. S. "Modeling and Simulation of Photovoltaic Module using MATLAB/Simulink," International Journal of Chemical and Environmental Engineering, Volume.2, No.5, pp 350-355, 2011.

[12] Pucker, G., Serra, E., \& Jestin, Y. "Silicon Quantum Dots for Photovoltaics," A review. Quantum Dots- A Variety of New Applications, ISBN: 978-953-51-0483-4, 2012 .

[13] Bagher, A. M., Vahid, M. M. A., \& Mohsen, M. "Types of Solar Cells and Application," American Journal of Optics and Photonics, Volume.3, No.5, pp 94-113, 2015.

[14] Zaknoon, B., Bahir, G., Saguy, C., Edrei, R., Hoffman, A., Rao, R. A.,.\& Chang, K. M. "Study of Single Silicon Quantum Dot's Band gap and Single-Electron Charging Energies by Room Temperature Scanning Tunneling Microscopy", Nano letters, Volume.8, No.6, pp 1689-1694 2008.

[15] Solarex MSX60 datasheet available online http:// www.californiasolarcenter.org/newssh/pdfs/SolarexMSX64.pdf. 